\title{
NEW RESULTS OF NUTRIENT UTILIZATION AND RESPONSE OF MAIZE (Zea mays L.) HYBRIDS
}

\author{
Péter PEPÓ - Lajos Gábor KARANCSI \\ Institute of Crop Scoience of Agricultural and Food Sciences of Environmental Management, Centre of Agricultural \\ Sciences, University of Debrecen, 138. Böszörményi út, Debrecen H-4032, Hungary \\ e-mail: pepopeter@agr.unideb.hu
}

\begin{abstract}
In a long-term experiment, the fertilizer response of 10 maize hybrids of different genotypes was studied on chernozem soil in a favourable year. The yields of the hybrids varied between 9500 and $18600 \mathrm{~kg} \mathrm{ha}^{-1}$ depending upon the fertilizer treatment and the genotype. The excellent nutrient and water management of the chernozem soil was proved by the high yield $\left(9500-14600 \mathrm{~kg} \mathrm{ha}^{-1}\right)$ obtained in the control. Even in such a good soil, the maize hybrids demanded fertilization and responded to it with a high yield increasement $\left(3200-6500 \mathrm{~kg} \mathrm{ha}^{-1}\right)$. From among the tested hybrids, 8 hybrids gave the highest yield in the $\mathrm{N}_{120}+\mathrm{PK}$ treatment, while 2 hybrids reached their maximum yield in the $\mathrm{N}_{150}+\mathrm{PK}$ fertilizer treatment $\left(13500-18600 \mathrm{~kg} \mathrm{ha}^{-1}\right.$ depending upon the hybrid). The water utilization of maize was improved as a result of the optimum fertilization. The water-use efficiency (WUE) was $30.35 \mathrm{~kg} \mathrm{~mm}^{-1}$, while it increased to $42.22 \mathrm{~kg} \mathrm{~mm}^{-1}$ at the optimum fertilizer dosage $\left(\mathrm{N}_{120}+\mathrm{PK}\right)$. The natural nutrient utilization ability (yield in the control treatment) and the yield obtained at the optimum fertilizer dosage $\left(\mathrm{N}_{120}+\mathrm{PK}\right.$ and $\mathrm{N}_{150}+\mathrm{PK}$ ) were used in a special coordinate system.
\end{abstract}

Keywords: maize, yield, fertilization, water utilization, nutrient efficiency

\section{Introduction}

The most critical factors determining maize yield are the water and the nitrogen supply (Moser et al., 2006). Nagy (1996) finds positive correlations between irrigation and fertilization as well as plant population and fertilization. Fertilization, irrigation, soil cultivation and plant population increased the yield by $48 \%, 28 \%$, $18 \%$ and $6 \%$, respectively. Maize is a plant that demands high amounts of nutrients and also requires and gives good responses professional fertilizer application (Pakurár et al., 2004). The cropyear and different agrotechnical factors (fertilization, crop rotation, irrigation etc) could modify the yields of different maize genotypes (Pepó et al., 2006; Berényi et al., 2007; Karancsi and Pepó, 2012). Széles et al. (2013) proved that the yield was influenced not only by the precipitation of the crop year, but also by the amount of precipitation and temperature during the winter. Results of Kuscu et al. (2013) proved that the better water supply resulted higher yields because the main limitation factor was water deficit. Huang et al. (2010) stated that imbalanced fertilization did not increase the yield of maize in the long run, furthermore, it resulted in soil acidification. Maize requires a balanced NPK fertilization and nitrogen has a determining role from among the macroelements (Kovačevic et al. 2006). Uribelarrea et al. (2007) found that the applied hybrid and the $\mathrm{N}$ supply have a great role in the $\mathrm{N}$ accumulation and in the efficacy of $\mathrm{N}$ uptake in maize. According to their results, the grain yield of maize increased gradually with increasing fertilizer doses up to the $\mathrm{N}_{160}$ fertilization level. On chernozem soils with medium-good NPK supply, the dosages above $120 \mathrm{~kg} \mathrm{ha}^{-1} \mathrm{~N}$ active ingredient did not increase yields efficiently, furthermore, they even reduced it without irrigation (Zhou et al, 2011). According to Azeez (2009), the dosage of $90 \mathrm{~kg} / \mathrm{ha} \mathrm{N}$ significantly increased the maize yield. As opposed to that, Berenguer et al. (2009) stated that the highest yields were obtained at 96, 153 and $159 \mathrm{~kg} \mathrm{ha}^{-1} \mathrm{~N}$ in 2003, 2004 and 2005, respectively. Idikut and Kara (2011) stated that the effect of nitrogen doses was significant for the tasseling period, 1000 grain yield of different maize varieties. Similar results were obtain in silage maize by Budakli Carpici et al. (2010). According to their results the dry matter yield 
responded linearly to nitrogen rates with the highest dry matter yield at $300-400 \mathrm{~kg} \mathrm{~N} \mathrm{ha}^{-1}$.

\section{Mateials and methods}

The experiment was carried out at the experimental farm of the University of Debrecen Centre for Agricultural Sciences, Institute of Crop Sciences at Látókép. The site is located in Eastern-Hungary, $15 \mathrm{~km}$ from Debrecen in the Hajdúság loess region and its soil is calcareous chernozem soil (N 473', E $\left.21^{\circ} 27^{\prime}\right)$. The experimental soil is of good culture-state, medium-hard loam. Its humus content is medium, $2.8 \%$, its $\mathrm{pH}$ value is almost neutral, $\mathrm{pH}_{\mathrm{Kcl}}=6.4$. The soil has good water management characteristics. The long-term experiment was set up in 1983. The hybrids studied in the experiment were P9578 (FAO 320), DKC 4014 (FAO 320), NK Lucius (FAO 330), P9175 (FAO 330), DKC 4025 (FAO 340), PR37M81 (FAO 360), DKC 4490 (FAO 370), PR37N01 (FAO 380), P9494 (FAO 390) and SY Afinity (FAO 470). The hybrids were sown with a seed number of 72.000 plants/ha. Six fertilization treatments were applied (Table 1). Nitrogen was applied in the form of $34 \%$ ammonium-nitrate $50 \%$ in the spring), the nitrogen $50 \%$ and the phosphorus and potassium fertilizers were applied in full dosage (100\%) in the autumn as a 10:15:18 special complex fertilizer. The forecrop was winter wheat. The major meteorological data are presented in Table 2.

\section{Results}

From among the field crops in Hungary, maize has the widest biological bases. Currently, the number of state registered hybrids is almost four hundred (390 hybrids on the variety list of 2013). There are great differences among the maize hybrids of different genetic background. The differences are manifested not only in the yield potential and yield stability of the given hybrid (in its abiotic and biotic adaptation ability), but also in the responses of the hybrids to the different agrotechnical inputs. The responses to the agrotechnical inputs have a great influence on the biological, agronomical and economic efficiency of maize production technology. From among the agrotechnical responses, one of the most important ones is the fertilizer response of maize hybrids, on the one hand, because fertilizer represent a very high cost, on the other hand, because overfertilization is not only ineffective from the economic point of view, but it can also indicate severe environmental problems.

In the vegetation period of 2013 , the fertilizer response of maize hybrids with different genetic

Table 1. Fertilizer doses of long-term experiment (Debrecen, chernozem soil)

\begin{tabular}{|c|c|c|c|}
\hline Treatment & $\mathrm{N}$ & $\begin{array}{c}\mathrm{P}_{2} \mathrm{O}_{5} \\
\mathrm{~kg} \mathrm{ha}^{-1}\end{array}$ & $\mathrm{~K}_{2} \mathrm{O}$ \\
\hline Control & 0 & 0 & 0 \\
\hline 1 & 30 & 22.5 & 26.5 \\
\hline 2 & 60 & 45 & 53 \\
\hline 3 & 90 & 67.5 & 79.5 \\
\hline 4 & 120 & 90 & 106 \\
\hline 5 & 150 & 112.5 & 132.5 \\
\hline
\end{tabular}

Table 2. Some important meteorological data (Debrecen)

\begin{tabular}{ccccccccc}
\hline Precipitation $(\mathrm{mm})$ & Oct-Feb. & March. & Apr. & May. & June & July & Aug. & Total \\
\hline 2012/2013 & 196.4 & 136.3 & 48.0 & 68.7 & 30.8 & 15.6 & 32.2 & 528.0 \\
30 years average & 186.7 & 33.5 & 42.4 & 58.8 & 79.5 & 65.7 & 60.7 & 527.3 \\
\hline Temperature $\left({ }^{\circ} \mathrm{C}\right)$ & Oct-Feb. & March. & Apr. & May. & June & July & Aug. & Average \\
\hline 2012/2013 & 3.7 & 2.9 & 12.0 & 16.6 & 19.6 & 21.2 & 21.5 & 13.9 \\
30 years average & 2.4 & 5.0 & 10.7 & 15.8 & 18.7 & 20.3 & 19.6 & 13.2 \\
\hline
\end{tabular}


Table 3. The effect of fertilization on the yield of maize hybrids $\left(\mathrm{kg} \mathrm{ha}^{-1}\right)$ (Debrecen, chernozem soil, 2013)

\begin{tabular}{lcccccc}
\hline Hybrids & Control & $\mathrm{N}_{30}+\mathrm{PK}$ & $\mathrm{N}_{60}+\mathrm{PK}$ & $\mathrm{N}_{90}+\mathrm{PK}$ & $\mathrm{N}_{120}+\mathrm{PK}$ & $\mathrm{N}_{150}+\mathrm{PK}$ \\
\hline P9578 & 11428 & 15710 & 15869 & 16105 & 16838 & 16475 \\
DKC 4014 & 9774 & 11846 & 12349 & 12437 & 13622 & 13011 \\
NK LUCIUS & 11237 & 14392 & 15112 & 15017 & 16572 & 15553 \\
P9175 & 11226 & 14880 & 15851 & 16311 & 16713 & 17736 \\
DKC 4025 & 9530 & 11011 & 12982 & 12299 & 13514 & 12943 \\
PR37M81 & 10630 & 14123 & 14611 & 14757 & 14838 & 16754 \\
DKC 4490 & 11148 & 12741 & 13790 & 14364 & 14789 & 14414 \\
PR37N01 & 14250 & 15641 & 15965 & 16519 & 17476 & 17127 \\
P9494 & 11293 & 14388 & 15092 & 16263 & 17132 & 15206 \\
SY AFINITY $^{14550}$ & 16570 & 16643 & 16736 & 18619 & 17718 \\
\hline LSD $_{5 \%}$ (Hybrid) & \multicolumn{7}{c}{1230} \\
LSD $_{5 \%}$ (Nutrient level) & \multicolumn{7}{c}{408} \\
\hline
\end{tabular}

backgrounds was studied on chernozem soil in a long-term experiment started 30 years ago. The weather of 2013 was favourable for the vegetative and generative development and yield formation of maize. As a joint effect of the favourable crop rotation (wheat - sunflower - wheat - maize), careful agrotechnique and favourable weather, the tested maize hybrids could realize a significant ratio of their yield potential. The yields of the hybrids ranged from 9500 to $18600 \mathrm{~kg} \mathrm{ha}^{-1}$ depending upon the hybrid and the fertilizer treatment (Table 3). The favourable physical, chemical and biological characteristics of the chernozem soil and its excellent water and nutrient management are well indicated by the high yields of the hybrids obtained in the control (non-fertilized) treatment. The yields of the hybrids varied between 9500 and $14600 \mathrm{~kg} \mathrm{ha}^{-1}$ in the control treatment. This means a difference of $5100 \mathrm{~kg} \mathrm{ha}^{-1}$ between the tested genotypes in 2013, which illustrates that there are huge differences between maize hybrids in their natural nutrient utilization ability. In 2013, the hybrids DKC 4025, DKC 4014, PR37M81 gave a relatively moderate yield in the control treatment $\left(9500-10600 \mathrm{~kg} \mathrm{ha}^{-1}\right)$. These hybrids had different FAO numbers, which indicates that the natural nutrient utilization ability of hybrids is primarily determined by the genotype. The hybrids PR37N01 and SY Afinity gave outstandingly high yields $\left(14200-14500 \mathrm{~kg} \mathrm{ha}^{-1}\right)$ in the control treatment in 2013, these hybrids also differed in their vegetation season-length.

In the season of 2013, the maximum yields of the hybrids varied within a very favourable range between 13500 and $18600 \mathrm{~kg} \mathrm{ha}^{-1}$ (Table $3)$. The yield maximum of the hybrids DKC 4025, DKC 4014 and DKC 4490 was relatively lower than the average (between 13500 and $14800 \mathrm{~kg} \mathrm{ha}^{-1}$ ). Outstandingly high yields were obtained in the case of the hybrids SY Afinity, P9175, PR37N01, and P9494 (between 17100 and $18600 \mathrm{~kg} \mathrm{ha}^{-1}$ ).

The evaluation of the nutrient utilization of the tested maize hybrids is included in Table 4. As

Table 4. Parameters of maize hybrids nutrient utilization (Debrecen, chernozem soil, 2013)

\begin{tabular}{ccc}
\hline & Average of 10 hybrids & $\begin{array}{c}\text { The minimum and maximum yield of } \\
\text { hybrids }\end{array}$ \\
\hline Control yield $\left(\mathrm{kg} \mathrm{ha}^{-1}\right)$ & 11507 & $9530-14550$ \\
Maximum yield $\left(\mathrm{kg} \mathrm{ha}^{-1}\right)$ & 16305 & $13514-18619$ \\
The yield surplus of fertilization $(\mathrm{kg}$ & 4798 & $3226-6510$ \\
$\left.\mathrm{ha}^{-1}\right)$ & $126 \mathrm{~N}+\mathrm{PK}$ & $120 \mathrm{~N}+\mathrm{PK}-150 \mathrm{~N}+\mathrm{PK}$ \\
\hline
\end{tabular}


Table 5. Study of nutrient efficiency of different maize genotypes (Average of ten hybrids) (Debrecen, chernozem soil, 2013)

\begin{tabular}{|c|c|c|c|c|c|c|}
\hline & Control & $\mathrm{N}_{30}+\mathrm{PK}$ & $\mathrm{N}_{60}+\mathrm{PK}$ & $\mathrm{N}_{90}+\mathrm{PK}$ & $\mathrm{N}_{120}+\mathrm{PK}$ & $\mathrm{N}_{150}+\mathrm{PK}$ \\
\hline $\begin{array}{l}\text { Average yield } \\
\left(\mathrm{kg} \mathrm{ha}^{-1}\right)\end{array}$ & 11507 & 14130 & 14826 & 15081 & 16011 & 15694 \\
\hline $\begin{array}{l}\text { Absolute yield } \\
\text { surplus of fertilization } \\
\left(\mathrm{kg} \mathrm{ha}^{-1}\right)\end{array}$ & - & 2623 & 696 & 255 & 930 & -317 \\
\hline $\begin{array}{l}\text { Relative yield surplus } \\
\text { of fertilization } \\
\left(\mathrm{kg} 1 \mathrm{~kg} \mathrm{NPK}^{-1}\right)\end{array}$ & - & 33.20 & 8.81 & 3.23 & 11.77 & -4.01 \\
\hline $\begin{array}{l}\text { WUE }\left(\mathrm{kg} \mathrm{mm}^{-1}\right) \\
\text { (Rainfall } \\
\text { March - Sept.) }\end{array}$ & 30.25 & 37.26 & 39.10 & 39.77 & 42.22 & 41.39 \\
\hline
\end{tabular}

an average of the tested 10 hybrids, the control and the maximum yields were $11507 \mathrm{~kg} \mathrm{ha}^{-1}$ and $16305 \mathrm{~kg} \mathrm{ha}^{-1}$, respectively. The minimum and maximum values of the hybrids in control treatment and maximum yields represent well the natural nutrient utilization ability and realized yield potential of the different genotypes. As an average of the 10 tested hybrids, the yield increasement due to fertilization was $4798 \mathrm{~kg}$ $\mathrm{ha}^{-1}$. The differences in the fertilizer response of the hybrids were proved by the minimum and maximum values of the yield increasement due to fertilization (3226 and $6510 \mathrm{~kg} \mathrm{ha}^{-1}$ ). The different fertilizer request was also proved by the optimum $\mathrm{N}+\mathrm{PK}$ fertilizer dosage. In 2013, the $\mathrm{N}_{120}+$ PK fertilizer dosage was the optimal (the maximum yield was obtained at this dosage) for most of the hybrids, however, the highest yield was obtained at the dosage of $\mathrm{N}_{150}+\mathrm{PK}$ in the case of two hybrids (P9175 and PR37M81). As for the latter, the importance of the genotype should be highlighted, that is the hybrids with different vegetation season length can be characterized by the same optimum fertilizer dosage. It should also be emphasized that the newest (P9175) and the old (PR37M81) genotypes also had the same optimum fertilizer dosage. Based on our experimental results, however, a trend could be observed that the more modern maize genotypes gave higher yields at the same or lower $\mathrm{N}_{\text {opt }}+\mathrm{PK}$ dosage in general, that is the fertilizer utilization ability of the hybrids was improved as a result of breeding.

When analysing the efficacy of fertilization and nutrient supply as an average of the ten tested hybrids (Table 5), it was found that the absolute yield increasement due to fertilization was the highest between the control and the $\mathrm{N}_{30}+\mathrm{PK}$ treatment $\left(2623 \mathrm{~kg} \mathrm{ha}^{-1}\right)$. In the fertilization treatments of higher dosage, the fertilization resulted in a more modest yield increment (696, 255 and $930 \mathrm{~kg} \mathrm{ha}^{-1}$ as an average of the hybrids), moreover, a small yield reduction $\left(-317 \mathrm{~kg} \mathrm{ha}^{-1}\right)$ was observed in the $\mathrm{N}_{150}+\mathrm{PK}$ treatment. The relative yield increasement due to fertilization was also calculated as an average of the hybrids (Table 5), this index represents the maize yield increasement due to $1 \mathrm{~kg}$ NPK fertilizer. As regards the relative yield increment due to fertilization, the most favourable value (33.20 kg $1 \mathrm{~kg} \mathrm{NPK}^{-1}$ ) was also obtained between the control and the $\mathrm{N}_{30}+\mathrm{PK}$ treatment, with increasing dosages, these valued were reduced $\left(8.81,3.23\right.$ and $\left.11.77 \mathrm{~kg}_{1} \mathrm{~kg} \mathrm{NPK}^{-1}\right)$ and then became negative $\left(-4.01 \mathrm{~kg} 1 \mathrm{~kg} \mathrm{NPK}{ }^{-1}\right)$. 
Figure 1. Complex evaluation of the nutrient response of maize hybrids (Debrecen, 2013)

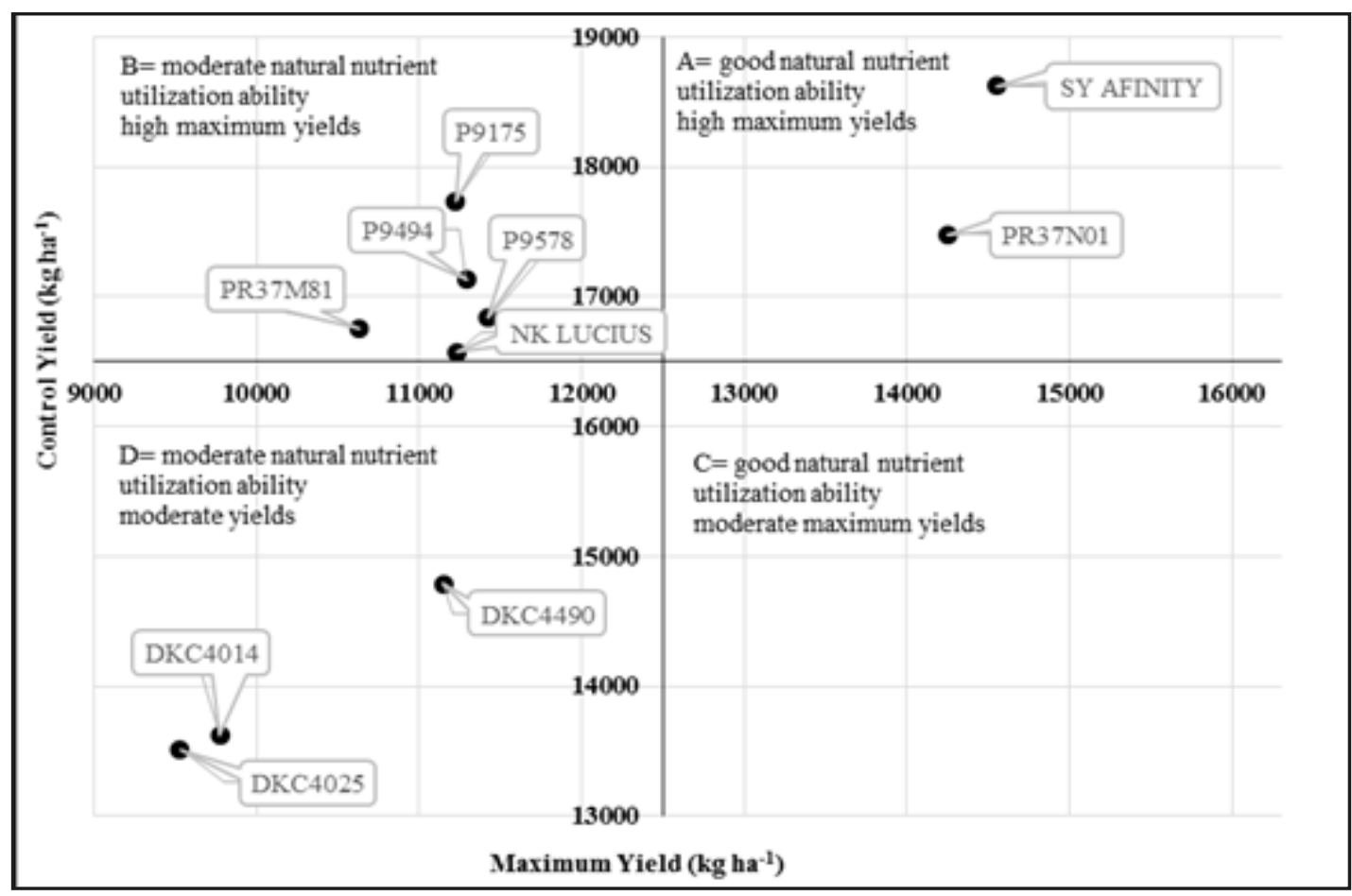

Results of our long-term experiments proved that there is a strong correlation between the nutrient and water supply of maize. A more favourable nutrient supply improved the water utilization of the maize hybrids (Table 5). As an average of the ten tested hybrids, the amount of yield per $1 \mathrm{~mm}$ precipitation from March 2013 until September 2013 was determined in the different fertilizer treatments. Our experimental results proved that a more favourable nutrient supply resulted in the improvement of water utilization by maize hybrids that is they could produce more yield from $1 \mathrm{~mm}$ precipitation. While the water use efficiency (WUE) was $30.25 \mathrm{~kg}$ $\mathrm{mm}^{-1}$ in the control treatment as an average of the tested hybrids, it increased to $42.22 \mathrm{~kg} \mathrm{~mm}^{-1}$ in the $\mathrm{N}_{120}+\mathrm{PK}$ fertilizer treatment.

For the complex evaluation of the fertilizer response of the tested maize hybrids such a graphic method was applied (Figure 1) which is suitable for the joint evaluation of

- the natural nutrient utilization ability (yield in the control treatment)

- the maximum yield due to fertilization (yield in the $\mathrm{N}_{\text {opt }}+\mathrm{PK}$ treatment).
For this evaluation, such a coordinate system was used in which the maximum yields and the control yields were presented in the ordinate (vertical) axis and the abscissa (horizontal) axis, respectively. In this way, such a coordinate system was created in which the hybrids with a different fertilizer response could be illustrated in the different quarters. Based on this, the tested maize hybrids could be classified into the following four fertilizer response groups:

$\mathrm{A}=$ hybrids which have a good natural nutrient utilization ability and give high maximum yields as a result of fertilization (SY Afinity, PR 37N01).

$\mathrm{B}=$ hybrids which have a moderate natural nutrient utilization ability and give high maximum yields as a result of fertilization ( $\mathrm{P}$ 9175, P 9494, PR 37M81, P 9578, NK Lucius).

$\mathrm{C}=$ hybrids which have a good natural nutrient utilization ability and give moderate maximum yields as a result of fertilization (-).

$\mathrm{D}=$ hybrids which have a moderate natural nutrient utilization ability and give moderate yields as a result of fertilization (DKC 4014, DKC 4025, DKC 4490). 
Those hybrids are the best for the production, which can utilize well both the natural nutrient stock of the soil and the applied fertilizers (group A). Those hybrids can also be favourable, which can significantly increase their relatively lower control yield as a result of fertilization (group B) (Figure 1).

\section{Discussion}

The results of our long-term experiment on chernozem soil in 2013 proved that fertilization is a very important agrotechnical element of maize production technology. Maize has extremely high productivity. The year and the weather have a significant yield-determining effect in maize production. In the experiment, the yields of the ten tested maize hybrids varied between 9500 and $18600 \mathrm{~kg} \mathrm{ha}^{-1}$ depending upon the fertilizer treatment. Very favourable yields were obtained also in the control, non-fertilized treatment (9500 $14600 \mathrm{~kg} \mathrm{ha}^{-1}$ ), which proved the excellent qualities and the good water and nutrient management of the chernozem soil. Fertilization had a yield-increasing effect even in spite of these high control yields. The maximum yield of the maize hybrids varied between 13500 and $18600 \mathrm{~kg} \mathrm{ha}^{-1}$ in 2013. The yield-increasing effect of fertilization was $4798 \mathrm{~kg}$ $\mathrm{ha}^{-1}$ as an average of the hybrids, ranging from 3226 to $6510 \mathrm{~kg} \mathrm{ha}^{-1}$ depending upon the genotype. As an average of the hybrids, the optimum fertilizer dosage was the $\mathrm{N}_{126}+\mathrm{PK}$. Berényi et al. (2007) proved that the maize had very good fertilizer response on chernozem soil.

The absolute yield increment due to fertilization was the highest between the control and the
$\mathrm{N}_{30}+\mathrm{PK}$ treatment (2623 $\mathrm{kg} \mathrm{ha}^{-1}$ as an average of the hybrids), then it decreased with increasing fertilizer dosages. A similar statement can be made for the relative yield-increment due to fertilization (the relative yield-increment between the control and the $\mathrm{N}_{30}+\mathrm{PK}$ treatment was $33.20-\mathrm{kg} 1 \mathrm{~kg} \mathrm{NPK}^{-1}$ (Kovacevic et al., 2006, Karancsi and Pepó, 2012).

Our experimental results proved that the water utilization of the maize hybrids can be improved with a proper nutrient supply and optimum fertilization. As an average of the hybrids, the WUE was $30.35 \mathrm{~kg} \mathrm{~mm}^{-1}$ in the control treatment, while it increased to $42.22 \mathrm{~kg} \mathrm{~mm}^{-1}$ in the optimum fertilization treatment.

Based on their fertilizer response, maize hybrids could be classified into different groups. Pepó (2006) proved the significance of hybrid-specific fertilization and the different nutrient utilization of maize hybrids based on their experimental results. For this classification, the nutrient utilization of the hybrids (yield in the control treatment), and the maximum yield due to fertilization (yield in the $\mathrm{N}_{\text {opt }}+\mathrm{PK}$ treatment) were used. Based on that, the tested hybrids can be classified into four different groups. As regards the nutrient utilization, those hybrids are the most valuable, which can significantly increase their good control yield as a result of fertilization. Our research results can successfully contribute to a better knowledge of maize genotypes, to the exploration of their traits and to a rational, environment-friendly application of fertilizers adapted to the given hybrid.

\section{References}

Azeez J. O. (2009): Effect of nitrogen application and weed interference on performance of some tropical maize genotypes in Nigeria. Pedosphere. 19:5. 654-662.

Berenguer P., Santiveri F., Boixadera J., Loveras J. (2009): Nitrogen fertilisation of irrigated maize under Mediterranean conditions. European Journal of Agronomy. 30:3. 163-171.

Berényi S., Vad A., Dóka L., Pepó P. (2007): Effects of fertilization and crop years on maize (Zea mays L.) yields in different crop rotations. Cereal Research Communications. 35: 2. 241-244.

Budakli Carpici E., Celik N., Bayram G. (2010): Yield and Quality of forage maize as influenced by plant density and nitrogen rate. Turkish Journal of Field Crops. 15:2. 128-132. 
Huang, S., Zhang, W., Yu, X., Huang Q. (2010): Effect of long-term fertilization on corn productivity and its sustainability in an Ultisol of southern China. Agriculture, Ecosystems and Environment. 138. 44-50. DOI: http://dx.doi.org/10.1016/j.agee.2010.03.015

Idikut L., Kara S. N. (2011): The effect of previous plants and nitrogen rates on second crop corn. Turkish Journal of Field Crops. 16:2. 239-244.

Karancsi L. G., Pepó P. (2012): Study of the effect of fertilization of maize (Zea mays L.) in crop years with different water-supply. Növénytermelés. 61: Suppl. 89-92.

Kovačevic V., Rastija M., Rastija D., Josipović M., Šeput M. (2006): Response of maize to fertilization with $\mathrm{KCl}$ on gleysol of Sava Valley Area. Cereal Research Communications. 34:2-3. 1129. DOI: http://dx.doi.org/10.1556/crc.34.2006.2-3.252

Kuscu H., Karasu A., Oz M., Demir A. O., Turgut I. (2013): Effect of irrigation amounts applied with drip irrigation on maize evapotranspiration, yield, water use efficiency, and net return in a sub-humid climate. Turkish Journal of Field Crops.18:1. 13-19.

Moser S. B., Feil B., Jampatong S., Stamp P. (2006): Effect of preanthesis drought, nitrogen fertilizer rate, and variety on grain yield, yield components, and harvest index of tropical maize. Agricultural Water Management. 81:1-2. 41-58. DOI: http://dx.doi.org/10.1016/j.agwat.2005.04.005

Nagy J. (1996): Effects of tillage, fertilization, plant density and irrigation on maize (Zea mays L.) yields. ActaAgronomica-Hungarica. 196. 44:4. 347-354.

Pakurar M., Nagy J., Jagendorf S. (2004): Fertilisation and irrigation effects on maize (Zea mays L.) grain production. Cereal Research Communications 32:1. 151-158.

Pepó P., Vad. A., Nagy J. (2006): Effect of some agrotechnical elements on the yield of maize on chernozem soil. Cereal Research Communications. 34:1. 621-624. DOI: http://dx.doi.org/10.1556/crc.34.2006.1.155

Széles A., Ragán P., Nagy J. (2013): The effect of natural water supply and fertilization on maize (Zea mays L.) yield in the case of different crop year. Növénytermelés. 62:Suppl. 119-122.

Uribelarrea M., Crafts-Brandner S. J., Below F. E. (2009): Physiological N response of field-grown maize hybrids (Zea mays L.) with divergent yield potential and grain protein concentration. Plant Soil. 316. 151-160. DOI: http://dx.doi.org/10.1007/s11104-008-9767-1

Zhou J. B., Wang C. Y., Zhang H., Gong F., Zheng X. F., Gate W., Li S. X. (2011): Effect of water saving management practices and nitrogen fertilizer rate on crop yield and water use efficiency in a winter wheat-summer maize cropping system. Field Crop Reasearch. 122:2. 157-163. DOI: http://dx.doi.org/10.1016/j.fcr.2011.03.009 
Columella - Journal of Agricultural and Environmental Sciences Vol. 1, No. 2 (2014) 